\title{
Penanaman Nilai-nilai Pendidikan Multikultural di Pondok Pesantren D DI-AD Mangkoso Barru Sulawesi Selatan
}

\author{
ZULQARNAIN \\ STAI Madinatunnajah Rengat, Indragiri Hulu \\ E-mail: dzulqarnainali07@gmail.com No hp.085340366555
}

\begin{abstract}
ABSTRAK: Penelitian ini berawal dari keinginan peneliti untuk melihat bagaimana penanaman nilai-nilai pendidikan multikultural yang terdapat di pondok pesantren DD-AD Mangkoso Barru Sulawesi Selatan dimana santri berasal dari berbagai daerah yang berbeda-beda dan tentunya budaya serta suku yang berbeda pula. Mereka kemudian dipersatukan dalam lingkungan pondok pesantren dan tinggal dalam asrama yang menjadi ciri khas pondok pesantren. Sangat menarik untuk diperhatikan bahwa dalam kehidupan dipondok pesantren terdapat serangkaian kegiatan yang dilaksanakan baik kegiatan formal disekolah maupun non formal diasrama dan juga kegiatan diluar pondok pesantren. Jenis penelitian ini merupakan penelitian lapangan (field research) dengan menggunakan metode deskriptif analitis, yaitu metode yang berusaha memaparkan secara sistematis materi-materi pembahasan yang berasal dari berbagai sumber untuk kemudian dianalisis dengan teliti guna memperoleh hasil sebagai kesimpulan. Metode pengumpulan data yaitu melalui observasi, wawancara, dan dokumentasi. Sedangkan pendekatan yang digunakan peneliti ialah pendekatan sosiologis-antropologis. Dari hasil penelitian diperoleh kesimpulan bahwa: 1) pada proses penanaman nilai-nilai pendidikan multikultural di pondok pesantren DDI-AD Mangkoso dilakukan melalui beberapa kegiatan. Pertama, kegiatan pembelajaran formal di sekolah. Kedua, kegiatan pengembangan diri. Ketiga, kegiatan pembiasaan diri. 2) nilainilai pendidikan mutikultural yang ditanamkan di pondok pesantren DDI-AD Mangkoso yaitu: a) penanaman nilai demokrasi dan saling menghargai. b) penanaman nilai toleransi dan saling menghormati. c) penanaman nilai keadilan sosial dan kesetaraan. d) penanaman nilai kebersamaan dan tolong menolong. 3)Adapun yang menjadi hambatan dan tantangan dalam penanaman nilai-nilai pendidikan multikultural ialah sarana dan prasarana yang masih kurang memadai khusunya asrama yang menjadi tempat tinggal santri dan masih kurangnya kompeten dan wawasan guru dalam mentransfer pengetahuan dan pada saat mengajar.
\end{abstract}

Kata Kunci: Nilai-Nilai Pendidikan Multikultural, Pondok Pesantren

\section{PENDAHULUAN}

Indonesia terdiri dari ribuan pulau dan ratusan suku dengan budayanya masing-masing. Dalam dunia yang semakin terbuka, maka perjumpaan dan pergaulan antar suku semakin mudah, di satu sisi kenyataan ini menimbulkan kesadaran akan perbedaan dalam berbagai aspek kehidupan. Perbedaan bila tidak dikelola dengan baik maka akan menimbulkan konflik, yang bahkan 
akhir-akhir ini menjadi kenyataan. Dilain pihak kenyataan ini juga menimbulkan kesadaran perlunya dan pentingnya dialog dalam kehidupan yang makin terbuka saat ini (Ujan, dkk, 2009: 16).

Masyarakat Indonesia merupakan masyarakat dengan tingkat keanekaragaman yang sangat kompleks, masyarakat dengan berbagai keanekaragaman tersebut dikenal dengan istilah masyarakat multikultural. Jika kita mengenal masyarakat sebagai sekelompok manusia yang telah cukup lama hidup dan bekerja sama sehingga mereka mampu mengorganisasikan dirinya dan berfikir tentang dirinya sebagai satu kesatuan sosial dengan batas-batas tertentu, maka konsep masyarakat tersebut jika digabungkan dengan multikultural memiliki makna yang sangat luas dan diperlukan pemahaman yang mendalam untuk dapat mengerti apa sebenarnya masyarakat multikultural itu.

Indonesia termasuk salah satu negara multikultural terbesar di dunia. Saat ini jumlah pulau yang ada di wilayah Indonesia mencapai 13.000 pulau besar maupun kecil dengan populasi penduduk lebih dari 200 juta jiwa yang terdiri dari sekitar 300 suku dan 200 bahasa yang berbeda. Selain itu, Indonesia juga merupakan multireligius, karena penduduknya menganut beragam agama, yakni Islam, Katolik, Kristen Protestan, Hindu, Budha, Konghuchu, serta berbagai macam aliran kepercayaan. Kemajemukan bangsa Indonesia tersebut selain merupakan khazanah kekayaan budaya nasional dan kekuatan bangsa, bisa juga menimbulkan berbagai problematika atau persoalan. Korupsi, kolusi, nepotisme, konflik politik, separatisme, kerusuhan antar etnis dan agama, merupakan bentuk nyata dari fenomena multikulturalisme tersebut dan hal itu merupakan bukti empiris persoalan multikulturalisme (Assegaf, 2011: 309).

Pendidikan bukan sekedar proses memindah ilmu pengetahuan (transfer of knowledge) dari seorang pendidik kepada peserta didik. Lebih dari itu, pendidikan juga dimaknai sebagai proses mentransfer nilai (transfer of values) dan kerja budaya yang menuntut kreativitas peserta didik untuk menjadi manusia sejati. Manusia sejati adalah simbol manusia yang berperadaban dan modern. Sebagai sebuah ide atau konsep, James Banks menyatakan bahwa pendidikan multikultural berarti pendidikan yang memberikan kesempatan yang sama kepada semua siswa (tanpa mengecualikan jenis kelamin, kelas sosial, etnis, ras, atau karakteristik budaya yang lain) dalam belajar di sekolah (Assegaf, 2011: 220).

Pembelajaran berbasis multikultural berusaha memberdayakan siswa untuk mengembangkan rasa hormat kepada orang yang berbeda budaya, memberi kesempatan untuk bekerja bersama dengan orang atau kelompok orang yang berbeda etnis atau rasnya. Menurut Savage dan Amstrong, pendidikan mulktikultural juga membantu siswa untuk mengakui ketepatan dari pandangan-pandangan budaya yang beragam, membantu siswa dalam mengembangkan kebanggaan terhadap warisan budaya mereka, dan menyadarkan siswa bahwa konflik nilai sering menjadi penyebab konflik antar kelompok masyarakat. Pendidikan multikultural diselenggarakan dalam upaya mengembangkan kemampuan siswa dalam memandang kehidupan dari berbagai perspektif budaya yang berbeda dengan budaya yang mereka miliki dan bersikap positif terhadap perbedaan budaya, ras, dan etnis (Thobroni \& Mustafa, 2011: 397). 
Dalam mengimplementasikan pendidikan multikultural di sekolah, maka sekolah harus dipandang sebagai sebuah sistem sosial dimana terdapat banyak variabel yang saling terkait dan berhubungan sangat erat. Berfikir tentang sekolah sebagai sistem sosial mengharuskan kita untuk membuat suatu rancangan strategi mengubah lingkungan sekolah secara total untuk menerapkan pendidikan multikultural. Salah satu variabel yang perlu mendapat perhatian adalah kurikulum yang tersembunyi (hidden curriculum) yang temasuk didalamnya adalah nilainilai dan norma sekolah. Aspek-aspek yang terdapat dalam lingkungan sekolah tersebut adalah hal penting yang harus di ubah sesuai dengan prinsip dan tujuan pendidikan multikultural sehingga tercipta budaya sekolah yang dapat meningkatkan sikap positif siswa terhadap perbedaan budaya yang yang ada dan membantu siswa dari kelompok budaya manapun dapat mencapai keberhasilan akademik (Maksum, 2011: 224-225).

Dalam lingkungan pondok pesantren juga tidak terlepas dari ragam budaya, etnis, suku, bahasa, dan daerah asal yang berbeda-beda tapi kita bisa menemukan sikap saling menghargai, menghormati dan kerjasama antar masyarakat dalam pondok pesantren yang begitu tinggi sehingga jarang terdengar dalam sebuah pondok pesantren terjadi konflik yang besar, lainnya halnya di sekolah umum atau oraganisasi masyarakat yang sering kali terjadi konflik di antara mereka, tawuran pelajar di mana-mana. Dari realita yang ada, hal tersebut menimbulkan pertanyaan-pertanyaan dan rasa peanasaran yang begitu dalam terhadap kondisi tersebut karna notabene, di pondok pesantrenlah yang lebih rawan muncul konflik atau gesekan-gesekan antar santri yang disebabkan keragaman etnis, suku, bahasa dan budaya yang berbeda-beda.

Dalam sebuah pesantren, kita pasti akan menemukan beberapa asrama yang dihuni oleh para santri yang mempunyai latar belakang yang berbeda sehingga kadang terjadi gesekan antar santri tersebut. Dari pandangan sekilas, kelihatannya biasabiasa saja tapi bisa jadi terdapat banyak masalah-masalah internal di antara santri yang tidak kita ketahui yang bisa saja masalah-masalah tersebut muncul karna perbedaan kultur di antara mereka. Disinilah dibutuhkan pendidikan multikultural untuk ditanamkan sejak dini dalam diri santri agar mampu menghargai setiap perbedaan di antara mereka. Berdasarkan hasil wawancara kami dengan salah seorang pembina di pondok pesantren DDI-AD Mangkoso Barru Sulawesi Selatan yang menjadi lokasi penelitian ini mengatakan bahwa bahwa salah satu cara untuk menghindari konflik atau gesekan yang sering terjadi di antara para pelajar dengan adanya penanaman nilai-nilai pendidikan multikultural.

Adapun muatan nilai-nilai pendidikan multikultural tersebut diantaranya tertuang dalam kurikulum pondok pesantren DDI-AD Mangkoso yang di aplikasikan lewat pengajian kitab-kitab kuning klasik maupun kontemporer setiap selesai shalat subuh dan setelah shalat maghrib yang kemudian dari hasil pembelajaran dari pengajian-pengajian tersebut, mereka para santri implementasikan dalam kehidupan sehari-hari melalui beberapa kegiatan seperti kegiatan pengembangan diri dan kegiatan pembiasaan diri. Hal tersebut merupakan salah satu bentuk kegiatan penanaman nilai-nilai pendidikan multikultural di madrasah-madrasah dalam lingkungan pondok pesantren DDI-AD Mangkoso. 
KONSEP TEORI

\section{Pendidikan Multikultural}

\section{Sejarah pendidikan Multikultural}

Pendidikan Multikultural lahir sesudah sekitar 30-an tahun yang silam, yaitu sesudah Perang Dunia II ditandai dengan lahirnya banyak negara dan berkembangnya prinsip-prinsip demokrasi. Dengan adanya gerakan kemerdekaan bukan hanya di negaranegara bekas jajahan, melainkan juga di negara-negara maju terjadi tantangan tentang prinsip hidup demokrasi (Tilaar, 2009: 204).

Dalam perkembangannya studi ini menjadi sebuah studi khusus tentang pendidikan multikultural yang pada awalnya bertujuan agar populasi mayoritas dapat bersikap toleran terhadap para imigran baru. Studi ini juga mempunyai tujuan politis sebagai alat kontrol sosial penguasa terhadap warganya agar kondisi negara aman dan stabil. Namun dalam perkembangannya, tujuan politis ini menipis bahkan hilang sama sekali karena ruh dan nafas dari pendidikan multikultural adalah demokrasi, humanisme, dan pluralisme yang menjadi motor penggerak dalam penegakannya yang dilakukan disekolah-sekolah, kampus, dan institusi-institusi pendidikan lainnya (Yaqin, 2005: 24).

Sejarah kelam yang panjang yang dialami negara-negara Eropa dan Amerika seperti kolonialisme, perang sipil di Amerika dan perang dunia I dan II, sebenarnya juga menjadi landasan utama sehingga pendidikan multikultural ini di aplikasikan di kedua benua tersebut. Perang dunia I yang diawali pada tahun 1914 dan kemudian berlanjut menjadi perang dunia II yang dimulai pada tahun 1939 yang berakhir hingga pertengahan tahun 1900-an telah menyebabkan negara-negara Eropa bercerai berai dan saling bermusuhan. Disisi lain, 1861-1865,
Amerika juga telah mengalami tragedi yang sangat menyakitkan yaitu perang sipil. Perang yang di akibatkan oleh adanya isu pertentangan ras dan etnis ini telah merenggut ratusan ribu jiwa. Perang dunia I dan II dan perang sipil di Amerika, telah menjadi bagian sejarah kelam dunia khususnya bagi bangsa Eropa dan Amerika (Yaqin, 2005: 22). Indonesia juga mempunyai pengalaman yang tidak kalah menyedihkan seperti kekerasan dan pemberontakan, pembumihangusan, dan pembunuhan generasi. Perpecahan dan ancaman disintegrasi bangsa telah terjadi sejak zaman kerajaan Singosari, Sriwijaya, Majapahit, Gowa, Mataram, hingga pada era terkini. Pembunuhan besar-besaran terhadap masa pengikut Partai Komunis Indonesia pada tahun 1965, kekerasan terhadap etnis Cina di Jakarta pada Mei 1998, perang Islam Kristen di Maluku Utara pada tahu 1999-2003, dan perang etnis antar warga Dayak dan Madura yang terjadi sejak tahun 1931 hingga tahun 2000 yang telah menelan korban jiwa kurang lebih 2000 nyawa manusia melayang sia-sia. Ini merupakan bahagian dari sejarah kelam bangsa Indonesia.

\section{Pengertian pendidikan Multikultural}

Sebelum jauh membahas tentang pengertian pendidikan multikultural, maka kita harus mengetahui lebih dulu definisi dari multikultural dan pendidikan itu sendiri. Multikultural berasal dari dua kata, yaitu multi yang berarti banyak atau beragam, dan kultural berarti budaya atau kebudayaan yang secara etimologi dapat diartikan sebagai keberagaman budaya. Dengan demikian, berarti beraneka ragam kebudayaan. Menurut Parsudi Suparlan sebagaimana yang dikutip Ali Maksum mengatakan bahwa akar kata dari multikulturalisme adalah kebudayaan, yaitu kebudayaan yang 
dilihat dari fungsinya sebagai pedoman bagi kehidupan manusia. Dalam konteks pembangunan bangsa, istilah multikultural ini telah membentuk suatu ideologi yang disebut multikulturalisme (Maksum, 2011: 143).

Abdullah dalam bukunya lebih lanjut menyatakan bahwa multikulturalisme adalah sebuah paham yang menekankan pada kesenjangan dan kesetaraan budayabudaya lokal dengan tanpa mengabaikan hak-hak dan eksistensi budaya yang ada. Dengan kata lain, penekanan utama multikulturalisme adalah pada kesetaraan budaya. Multikulturalisme merupakan suatu paham atau situasi kondisi masyarakat yang tersusun dari banyak kebudayaan. Multikulturalisme merupakan perasaan nyaman yang dibentuk oleh pengetahuan yang dibangun oleh keterampilan yang mendukung suatu proses komunikasi yang efektif, dengan setiap orang dari sikap kebudayaan yang ditemui dalam setiap situasi yang melibatkan sekelompok orang yang berbeda latar belakang kebudayaannya. Multikulturalisme sebenarnya merupakan konsep dimana sebuah komunitas dalam konteks kebangsaan dapat mengakui keberagaman, perbedaan, kemajemukan budaya, baik ras, suku, etnis, dan agama (Naim \& Sauqi, 2011: 126).

Pendidikan multikultural secara etimologi berasal dari dua term yakni pendidikan dan multikultural. Pendidikan dapat diartikan sebagai proses pengembangan sikap dan tingkah laku seseorang atau kelompok orang dalam usaha mendewasakan manusia melalui upaya pengajaran, pelatihan, proses, perbuatan, dan caracara yang mendidik. Sedangkan istilah multikultural sebenarnya merupakan kata dasar yang mendapat awalan. Kata dasar tersebut adalah kultur yang berarti kebudayaan, kesopanan, atau pemeliharaan, sedangkan awalannya adalah multi yang berarti banyak, ragam, dan aneka. Dengan demikian, multikultural berarti keragaman budaya, aneka, kesopanan, atau banyak pemeliharaan, namun dalam tulisan ini lebih diartikan sebagai keragaman budaya sebagai aplikasi dari keragaman seseorang.

Pendidikan multikultural didefenisikan oleh Banks sebagai sebuah kebijakan sosial yang didasarkan pada prinsip-prinsip pemeliharaan budaya dan saling memiliki rasa hormat antara seluruh kelompok budaya di dalam masyarakat. Pembelajaran multikultural pada dasarnya merupakan program pendidikan bangsa agar komunitas multikultural dapat berpartisipasi dalam mewujudkan kehidupan demokrasi yang ideal bagi bangsanya (Thobroni \& Mustafa, 2011: 396). Lanjut dari pengertian di atas, Sebagai ide atau konsep, James Banks menyatakan bahwa pendidikan multikultural berarti pendidikan yang memberikan kesempatan yang sama kepada semua siswa (tanpa mengecualikan jenis kelamin, kelas sosial, etnis, ras, atau karakteristik budaya yang lain) dalam belajar disekolah.

Dengan melihat dan memperhatikan berbagai pengertian atau definisi pendidikan multikultural diatas, maka dapat disimpulkan bahwa pendidikan multikultural adalah sebuah proses pengembangan yang tidak mengenal sekat-sekat dalam interaksi manusia. Sebagai wahana pengembangan potensi, pendidikan multikultural adalah pendidikan yang menghargai heterogenitas dan pluralitas, pendidikan yang menjunjung tinggi nilai kebudayaan, etnis, suku, dan agama serta menghargai dan 
menghormati keragaman budaya yang ada di dalam kehidupan masyarakat.

\section{Dimensi pendidikan Multikultural}

James Banks menjelaskan bahwa pendidikan multikultural memiliki lima dimensi yang saling berkaitan, yakni: (a) Content Intergration: Mengintegrasikan berbagai budaya dan kelompok untuk mengilustrasikan konsep mendasar, generalisasi, dan teori dalam mata pelajaran/disiplin ilmu; (b) The Knowledge Contruction Process: Membaca siswa untuk memahami implikasi budaya ke dalam sebuah mata pelajaran (disiplin); (c) $A n$ Pedagogy: Menyesuaikan metode pengajaran dengan cara belajar siswa dalam rangka memfasilitasi prestasi akademik siswa yang beragam baik dari segi ras, budaya maupun sosial; (d) Prejudice Reduction: Mendefenisikan karakteristik ras siswa dan menentukan metode pengajaran mereka; dan (e) Melatih kelompok untuk berpartisipasi dalam kegiatan olahraga, berinteraksi dengan seluruh staf dan siswa yang berbeda etnis dan ras dalam upaya menciptakan budaya akademik.

\section{Pendekatan Pendidikan Multikultural}

Dalam mengkaji sebuah pendekatan, Banks menawarkan empat pendekatan dalam pendidikan multikultural, yaitu: pendekatan kontributif, aditif, aksi sosial, dan transformatif. Adapun pendekatanpendekatan yang ditawarkan Banks tersebut akan dijelaskan sebagai berikut: (a) Pendekatan kontributif. Pendekatan kontributif adalah pendekatan yang dilakukan dengan cara menyeleksi buku-buku teks wajib atau anjuran dan aktivitas-aktivitas tertentu seperti hari-hari besar kenegaraan dan keagamaan dari berbagai macam kebudayaan; (b) Pendekatan aditif. Pendekatan aditif merupakan bentuk penambahan muatan-muatan, tematema, dan persfektif- persfektif ke dalam kurikulum tanpa mengubah struktur dasarnya. Pendekatan ini melibatkan upaya memasukkan literatur oleh dan tentang masyarakat dari berbagai kebudayaan ke dalam meainstream kurikulum;

Pendekatan transformatif. Pendekatan transformatif yaitu mengembangkan suatu paradigma baru bagi kurikulum atau membuat kurikulum baru dimana konsep-kosep, isu-isu, tema-tema dan problem-problem didekati dengan pendekatan muqaran (perbandingan) untuk memperbaharui pemahaman, presfektif dan sudut pandang; dan (d) Pendekatan Aksi Sosial. Pendekatan aksi sosial yaitu mengkombinasikan pendekatan transformatif dengan berbagai aktivitas untuk melakukan perubahan sosial (Sulalah, 2012: 127128).

\section{Nilai-nilai Multikultural Dalam Pendidikan Islam}

Adapun pembahasan terkait dengan nilai-nilai multikultural menurut Abdullah Aly terdapat kesesuaian antara nilai-nilai multikultural persektif Barat dengan nilai-nilai multikultural persektif Islam. Namun demikian, sumber kebenaran dari nilai-nilai multikultural dalam persfektif Barat bersumber dari filsafat yang bertumpu pada hak-hak asasi manusia, maka nilai-nilai multikultural dalam persfekti Islam bersumber pada wahyu (aly, 2011: 124). Adapun pembagiannya terdapat pada tabel berikut: 


\section{Tabel 1: Perbedaan Karakteristik Nilai Multikultural antara}

Perspektif Barat dan Perspektif Islam

\begin{tabular}{lll}
\hline \multicolumn{1}{c}{ Karakteristik } & \multicolumn{1}{c}{$\begin{array}{c}\text { Nilai multikultural } \\
\text { persfektif Barat }\end{array}$} & $\begin{array}{l}\text { Nilai multikultural } \\
\text { persfektif Islam }\end{array}$ \\
\hline $\begin{array}{l}\text { Berprinsip pada } \\
\text { demokrasi, kesetaraan, } \\
\text { dan keadilan }\end{array}$ & $\begin{array}{l}\text { Demokrasi, kesetaraan } \\
\text { dan keadilan }\end{array}$ & $\begin{array}{l}\text { Al-musyawarah, al- } \\
\text { musawah dan al-'adl }\end{array}$ \\
\hline $\begin{array}{l}\text { Berprinsip pada } \\
\text { demokrasi, kesetaraan, } \\
\text { dan keadilan }\end{array}$ & $\begin{array}{l}\text { Kemanusiaan, } \\
\text { kebersamaan, dan } \\
\text { kedamaian }\end{array}$ & $\begin{array}{l}\text { Hablum min al-nas, al- } \\
\text { ta'aruf, al-ta'awun, dan as- } \\
\text { salam }\end{array}$ \\
\hline $\begin{array}{l}\text { Mengembangkan sikap } \\
\text { mengakui, menerima dan } \\
\text { menghargai keragaman }\end{array}$ & $\begin{array}{l}\text { Toleransi, empati, simpati } \\
\text { dan solidaritas sosial }\end{array}$ & $\begin{array}{l}\text { Al-ta'adudiyat, al- } \\
\text { tanawwu'al-tsamuh, al- } \\
\text { 'afw, dan al-ihsan }\end{array}$ \\
\hline
\end{tabular}

Sedangkan terkait dengan muatan nilai-nilai multikultural dalam Islam, Prof. Assegaf lebih lengkap dan terperinci membagi ke dalam tiga kategori. Pertama, nilai-nilai utama yang meliputi: Tauhid (mengesakan Tuhan), ummah (hidup bersama), rahmah (kasih sayang), al-musawah, taqwa (egalitarianism). Kedua, nilainilai-nilai penerapan: Ta'aruf, ihsan (saling mengenal dan berbuat baik), tafahum (saling memahami), takrim (saling menghormati), fastabiqul khayrat (berlomba dalam kebaikan), amanah (saling mempercayai), husnuzhan (berfikir positif), tasamuh (toleransi), 'afw, magfirah (pemberian/permohonan ampun), sulh (perdamaian), islah (resolusi konflik). Ketiga: nilai-nilai tujuan: silah, salam (perdamaian), layyin (lemah lembut atau budaya anti-kekerasan), dan 'adl (keadilan) (Assegaf, 2011: 313-314).

\section{Pendidikan dalam pesantren Pengertian pondok pesantren}

Istilah pondok pesantren dimaksudkan suatu bentuk pendidikan ke-Islaman yang melembaga Indonesia. Kata pondok (kamar, gubuk, rumah kecil) dipakai dalam bahasa Indonesia dengan menekankan kesederhanaan bangunan. Sedangkan kata pesantren yang terdiri dari asal "santri" awalan "pe" dan akhiran "an" yang menentukan tempat, yang berarti tempat para santri. Dalam arti yang paling umum pondok pesantren mungkin dibedakan pusat ibadah Islam, mesjid, yang dapat diartikan sebagai lembaga pengajaran dan pelajaran ke-Islaman (Ziemek, t.t.: 99).

Menurut Soegarda Poerbakawtja seperti yang dikutip Haidar Putra Daulay mengatakan bahwa pesantren berasal dari kata santri yaitu seorang yang belajar agama Islam, sehingga dengan demikian pesantren mempunyai arti tempat orang berkumpul untuk belajar agama Islam. Ada juga yang mengartikan pesantren adalah suatu lembaga pendidikan Islam Indonesia yang bersifat tradisional untuk mendalami ilmu agama Islam dan mengamalkannya sebagai pedoman hidup keseharian (Daulay, 2004: 26).

Bentuk Pesanteran yang tersebar di Indonesia dewasa ini mengandung unsur-unsur yang cirinya adalah: Kyai sebagai pendiri, pelaksana dan guru, pelajar (santri) yang secara pribadi langsung diajar berdasarkan naskahnaskah Arab klasik tentang pengajaran, faham, dan aqidah ke-Islaman. Disini, 
Kyai dan santri tinggal bersama-sama untuk masa yang lama, membentuk suatu komune pengajar dan belajar, yaitu pesantren bersifat asrama (tempat pendidikan, pemondokan dan makan) (Daulay, 2004: 101).

Dorongan pemerintah atas pesantren untuk memperluas dasar pendidikannya pada umumnya terlau membebani subyek. Juga ukuran kelas menjadi kelewat besar dan tugas guru terlalu berat serta hasil yang dibawah "standar pendidikan". Peribadatan, pengkajian dan penyebaran Islam merupakan dasar pemikiran inti bagi sebuah pesantren. Ada rasa enggan untuk mengorbankan aspek kajian keagamaan bagi kepentingan akademis umum (Daulay, 2004: 123).

\section{Metode dan sistem Pengajaran dalam Pesantren}

Dalam dunia pesantren pelestarian pengajaran kitab-kitab klasik berjalan terus-menerus dan secara kultural telah menjadi ciri khusus pesantren sampai saat ini. Di sini peran kelembagaan pesantren dalam meneruskan tradisi ke-Ilmuan Islam klasik sangatlah besar. Pengajaran kitab-kitab klasik tersebut pada gilirannya telah menumbuhkan warna tersendiri dalam bentuk paham dan sistem nilai tertentu. Sistem nilai ini berkembang secara wajar dan mengakar dalam kultur pesantren, baik yang terbentuk dari pengajaran kitabkitab klasik, maupun yang lahir dari pengaruh lingkungan pesantren itu sendiri (Yasmadi, 2002: 90).

Kurikulum pesantren sebenarnya meliputi seluruh yang dilakukan di pesantren selama sehari semalam (yang saat itu belum dirumuskan). Diluar proses pembelajaran, banyak kegiatan yang bernilai pendidkan dilakukan di pondok berupa latihan hidup sederhana, mengatur kepentingan bersama, mengatur kebutuhan seharihari, olahraga, belah diri, belajar bersama, ibadah dengan tertib dan lain sebagainya (Rahardjo, 1995: 86).

Adapun metode pengajarannya, sebenarnya adalah suatu hal yang setiap kali dapat berkembang dan berubah sesuai dengan penemuan metode yang lebih efektif dan efesien untuk mengajarkan masing-masing cabang ilmu pengetahuan. Meskipun demikian, dalam waktu yang sangat panjang, pesantren secara seragam menggunakan metode pengajaran yang lazim disebut sebagai weton dan sorogan (Rahardjo, 1995: 87).

\section{Pesantren dan Pembentukan Masyarakat Madani}

Menurut Nurcholis, masyarakat madani itu adalah masyarakat yang mengacu kepada masyarakat Madinah yang berada dibawah pimpinan Rasulullah ketika beliau hijrah ke Madinah. Beliau membangun tatanan kehidupan masyarakat yang berperadaban (Daulay, 2004: 31).

Masyarakat madani dijadikan acuan oleh pondok pesantren guna membentuk masyarakat dengan melihat ciri-ciri dari masyarakat madani. Adapun ciri-ciri dari masyarakat madani adalah: (a) Masyarakat Rabbaniyah, adalah masyarakat yang didasarkan atas dasar ketuhanan yang dilandasi atas tiga pilar yaitu: akidah, syariah, dan akhlak.; (b) Masyarakat demokratis dan egalitarian. Kehidupan santri sangat demokratis dan egalitarian dimana mereka hidup tanpa disekat oleh status sosial dan ekonomi; (c) Hidup toleran, salah satu di antara kehidupan yang dikembangkan adalah hidup bertoleransi sesama mereka. Menghargai orang lain, mengembangkan hidup tenggang rasa, mengikis sikap-sikap egois, 
ditumbuhkan semangat persaudaraan (ukhuwah); (d) Berkeadilan, sikap yang berkeadilan ini timbul dari sikap kiai yang memberikan pendidikan, perhatian, serta kasih sayang yang sama kepada santri; dan (e) Masyarakat berilmu. Pesantren adalah lembaga untuk menimba ilmu oleh karena itu pesantren tentu saja dapat dipastikan bahwa pesantren tidak dapat dipisahkan dengan ilmu (Daulay, 2004: 24-25).

\section{HASIL DAN PEMBAHASAN}

\section{Nilai-Nilai Pendidikan Multikultural} di Pondok Pesantren DDI Mangkoso

Berdasarkan hasil analisis data dari observasi, wawancara, dokumentasi dan data-data yang mendukung penelitian ini yang terkait dengan penanaman nilai-nilai pendidikan multikultural di madrasah berbasis pondok pesantren DD-AD Mangkoso Barru Sulawesi Selatan yang telah diuraikan dalam bab-bab sebelumnya, maka pada bab ini peneliti dapat menyimpulkan sebagai berikut:

\section{Proses penanaman nilai-nilai pendidikan multikultural di madrasah berbasis pondok pesantren DDI-AD Mangkoso Barru Sulawesi Selatan}

Dalam proses penanaman nilainilai pendidikan multikultural di madrasah berbasis pondok pesantren DDI-AD Mangkoso, pembina dan guruguru dapat menerapkannya melalui beberapa kegiatan seperti kegiatan formal sekolah berupa kegiatan belajar mengajar dan kegiatan non formal melalui kegiatan pengembangan diri dan kegiatan pembiasaan diri.

\section{Kegiatan belajar mengajar}

Proses penanaman nilai-nilai pendidikan multikultural di madarasah dapat diimplementasikan melaui kegiatan belajar mengajar formal di sekolah dan kegiatan belajar mengajar non formal melalui kegiatan pengajin dengan menekankan pada aspek moral dan akhlak terpuji yang termuat dalam materi pelajaran.

\section{Kegiatan pengembangan diri}

Kegiatan pengembangan diri merupakan upaya untuk membentuk watak, karakter dan kepribadian peserta didik yang dilakukan melalui beberapa kegiatan ekstrakurikuler. Kegiatan pengembangan diri tersebut berupa latihan dasar kepimpinan santri, kepramukaan, olahraga, seni dan budaya, drum band, latihan dakwah dan kegiatan pengajian kitab kuning yang rutin dilaksanakan setelah selesai solat magrib dan subuh.

\section{Kegiatan pembiasaan diri}

Program pembiasaan diri mencakup kegiatan yang bersifat pembinaan karakter peserta didik. Adapun bentuk pelaksanaan kegiatan pengembangan diri tersebut meliputi: kegiatan terprogram, kegiatan rutin, kegiatan spontan, dan kegiatan keteladanan.

Adapun kegiatan terprogram meliputi: Latihan Dasar Kepemimpinan Santri (LDKS), Daurah Mubaligh (Pelatihan Muballigh), Pentas Dakwah, Porseni dalam rangka Milad.

Sedangkan bentuk pelaksanaan kegiatan rutin adalah upacara bendera setiap hari Senin, shalat berjamaah lima waktu di mesjid/aula, shalat berjamaah dhuha sebelum pelajaran di sekolah di mulai dan setelah berakhirnya pelajaran dilanjutkan dengan salat zuhur secara berjamaah pula dan mudzakarah atau diskusi (belajar bersama) setiap pukul 21.00-22.30. 
Bentuk pelaksanaan kegiatan spontan adalah budaya antri pada saat pengambilan ransum, memberi salam kepada guru pada waktu awal dan akhir pelajaran, membuang sampah pada tempatnya, menghentikan semua aktivitas sore pada saat shalawat di masjid.

Bentuk Pelaksanaan kegiatan keteladanan meliputi: memberi contoh berpakaian rapi, memberi contoh hidup sederhana dan memberi contoh tidak merokok.

Keseluruhan rangkaian kegiatan tersebut mengandung beberapa nilainilai pendidikan multikutural, yaitu: demokrasi, keadilan, kerjasama, disiplin, saling menghargai, saling menghormati, bertanggung jawab, belajar hidup bersama atau berdampingan dengan kelompok lain yang berbeda, saling tolong-menolong, keragaman budaya, keberagaman bahasa, toleransi antar suku yang berbeda dan lain sebagainya.

\section{Nilai-nilai Pendidikan Multikultural yang di tanamkan di pondok pesantren DDI-AD Mangkoso Barru Sulawesi Selatan \\ Penanaman nilai demokrasi dan saling menghargai}

Dalam lingkungan pondok pesantren DDI-AD Mangkoso, semua santri diajarkan tentang demokrasi baik itu dalam kegiatan formal sekolah yang termuat dalam beberapa mata pelajaran, lewat pengajian yang di adakan setiap selesai sholat subuh dan maghrib serta lewat kegiatan organisasi ISIM dan OSKN. Contoh kegiatan perilaku demokrasi terdapat dalam musyawarah guru yang dilaksanakan pada saat rapat dan musyawarah santri dalam kegiatan ISIM dan OSKN dengan saling menghargai atau menerima setiap hasil keputusan rapat.

\section{Penanaman nilai toleransi dan saling menghormati}

Toleransi diajarkan melalui pembelajaran formal sekolah maupun pembelajaran lewat kegiatan pengajian. Disamping itu dapat ditanamkan melalui kegiatan Ordas dengan mengadakan Porseni antar Ordas dan melalui Peringatan Hari Besar Nasional (PHBN) yang dilakukan dengan berbagai bentuk kegiatan serta meliburkan para santri pada saat Peringatan Hari Besar Agama (PHBA).

\section{Penanaman nilai keadilan dan kesetaraan}

Keadilan di kalangan santri maupun pembina di lingkungan pondok pesantren mangkoso juga dapat dilihat dari beberapa kebijakan yang dikeluarkan oleh pihak kampus. Seperti terkait dengan larangan memakai celana levis dan larangan membawa barang-barang elektronik ke dalam lingkungan pondok pesantren. Tentunya ini bukan larangan yang tidak beralasan tapi untuk menghindari rasa kecemburuan sosial antara santri yang satu dengan santri lainnya.

\section{Penanaman nilai kebersamaan, kerjasama dan tolong menolong}

Dalam kehidupan santri diasrama juga ditanamkan nilai kebersamaan dan sikap tolong-menolong. Apabila ada santri yang memerlukan pertolongan maka santri-santri yang lain secara spontan memberikan pertolongan tanpa ada permintaan dari santri yang bersangkutan. Adapun beberapa kegiatan yang memuat nilai kebersamaan santri di luar dari jam belajar formal disekolah yang juga menjadi program kurikulum pesantren adalah: Kegiatan pengajian yang dilaksanakan setiap selesai sholat 
magrib dan subuh secara bersamasama, Sholat dhuha dan zuhur bersama secara bejamaah, Muzakarah (Belajar bersama) dan Makan bersama.

\section{Hambatan dan Tantangan penanaman nilai-nilai pendidikan multikultural di madrasah berbasis pondok pesantren DDI-AD Mangkoso Barru Sulawesi Selatan}

Dalam proses penanaman nilainilai multikultural dilingkungan pondok pesantren DDI-AD Mangkoso tentunya juga mempunyai beberapa kendala, baik itu berupa hamabatan ataupun tantangan. Dari penulusuran penulis setelah melakukan observasi dan wawancara dengan beberapa pembina dan guru, hampir semua masih mengeluhkan infrastruktur yang ada di pondok pesantren khususnya asrama yang menjadi tempat santri berbaur dengan santri-santri lainnya dan tentunya hal tersebut membutuhkan perhatian yang serius agar dilingkungan pondok pesantren bisa tercipta suasana yang menyenangkan.

Kendala lainnya yang penghambat dalam proses penanaman nilai-nilai multikultural di lingkungan pondok pesantren DD-AD Mangkoso khususnya pada pelajaran formal di sekolah adalah masih ada beberapa guru yang kurang kompeten dalam mengajar serta kurangnya wawasan dalam proses pengajaran. Dalam menamamkan nilainilai pendidikan multikultural, seorang guru tidak hanya dituntut untuk mampu secara profesional mengajarkan mata pelajaran yang diampuhnya akan tetapi harus mampu menanamkan nilainilai keberagaman yang inklusif kepada para santri olehnya itu guru atau pendidik harus memiliki minimal empat kompetensi, yaitu: pedagogik, komptensi personal, kompetensi sosial, dan kompetensi profesional.

Sedangkan yang menjadi tantangan dalam penanaman nilai-nilai pendidikan multikultural tersebut bermula dari pendidikan multikultural belum mampu berdiri sebagi mata pelajaran. Untuk itu, perlu adanya upaya integrasi dalam mata pelajaran lain. Pendidikan multikultural merupakan gerakan pembaharuan pendidikan dan proses untuk melatih dan membangun karakter peserta didik agar tertanam nilai-nilai humanis, pluralis, demokratis yang mampu diaplikasikan dalam kehidupan seharihari. Dari latar belakang budaya santri yang beragam adalah merupakan tantangan yang harus menjadi perhatian penuh oleh pembina dan guru agar para santri tidak merasa ada diskriminasi dan ketidakadilan yang tercipta sehingga mereka bisa hidup rukun dan tentram dalam kebersamaan.

\section{SIMPULAN}

Dalam proses penanaman nilainilai pendidikan multikultural di pondok pesantren DDI-AD Mangkoso, pembina dan guru-guru dapat menerapkannya melalui beberapa kegiatan seperti kegiatan formal sekolah berupa kegiatan belajar mengajar dan kegiatan non formal melalui kegiatan pengembangan diri dan kegiatan pembiasaan diri.

Adapun keseluruhan rangkaian kegiatan tersebut mengandung beberapa nilai-nilai pendidikan multikutural, yaitu: demokrasi, keadilan, kerjasama, disiplin, saling menghargai, saling menghormati, bertanggung jawab, belajar hidup bersama atau berdampingan dengan kelompok lain yang berbeda, saling tolong-menolong, keragaman budaya, keberagaman bahasa, toleransi antar suku yang berbeda dan lain sebagainya.

Dalam proses penanaman nilainilai multikultural dilingkungan pondok pesantren DDI-AD Mangkoso tentunya juga mempunyai beberapa kendala, 
baik itu berupa hamabatan ataupun tantangan. Dari penulusuran penulis setelah melakukan observasi dan wawancara dengan beberapa pembina dan guru, hampir semua masih mengeluhkan infrastruktur yang ada di pondok pesantren khususnya asrama yang menjadi tempat santri berbaur dengan santri-santri lainnya dan tentunya hal tersebut membutuhkan perhatian yang serius agar dilingkungan pondok pesantren bisa tercipta suasana yang menyenangkan.

Kendala lainnya yang penghambat dalam proses penanaman nilai-nilai multikultural di lingkungan pondok pesantren DD-AD Mangkoso khususnya pada pelajaran formal di sekolah adalah masih ada beberapa guru yang kurang kompeten dalam mengajar serta kurangnya wawasan dalam proses pengajaran. Dalam menamamkan nilainilai pendidikan multikultural, seorang guru tidak hanya dituntut untuk mampu secara profesional mengajarkan mata pelajaran yang diampuhnya akan tetapi harus mampu menanamkan nilainilai keberagaman yang inklusif kepada para santri olehnya itu guru atau pendidik harus memiliki minimal empat kompetensi, yaitu: pedagogik, komptensi personal, kompetensi sosial, dan kompetensi profesional.

Sedangkan yang menjadi tantangan dalam penanaman nilai-nilai pendidikan multikultural tersebut bermula dari pendidikan multikultural belum mampu berdiri sebagi mata pelajaran. Untuk itu, perlu adanya upaya integrasi dalam mata pelajaran lain. Pendidikan multikultural merupakan gerakan pembaharuan pendidikan dan proses untuk melatih dan membangun karakter peserta didik agar tertanam nilai-nilai humanis, pluralis, demokratis yang mampu diaplikasikan dalam kehidupan seharihari. Dari latar belakang budaya santri yang beragam adalah merupakan tantangan yang harus menjadi perhatian penuh oleh pembina dan guru agar para santri tidak merasa ada diskriminasi dan ketidakadilan yang tercipta sehingga mereka bisa hidup rukun dan tentram dalam kebersamaan.

Adapun beberapa rekomendasi yang penulis dapat berikan, yaitu: (a) Memaksimalkan asrama sebagai salah satu kelebihan yang menjadi ciri khas pesantren dalam menanamkan nilainilai multikultural kepada santri yang mempunyai latar belakang budaya yang berbeda; (b) Jadikan lingkungan asrama menjadi sarana yang baik untuk meningkatkan kualitas pendidikan diluar jam pelajaran formal sekolah; (c) Gunakan sarana dan prasarana yang ada semaksimal mungkin untuk dapat bersaing terhadap kemajuan ilmu pengetahuan dan teknologi yang terus berkembang utamanya dalam meningkatkan prestasi santri; (d) Lebih meningkatkan pengawasan terhadap kegiatan-kegiatan yang ada dalam pondok pesantren agar tidak tercipta kehidupan yang diskriminasi dan ketidakadilan; (e) Laksanakan semaksimal mungkin program kegiatan-kegiatan yang ada dalam pondok pesantrenagar bisa bersaing dengan sekolah umum dan sekolah islam yang juga menerapkan sistem asrama; (f) Permantapkan SDM pendidik sebagai pembina santri pada kegiatan proses pembelajaran baik disekolah maupu diasrama; (g) Meningkatkan pengawasan dari kegiatan-kegiatan baik kegiatan umum maupun kegiatan keagamaan yang ada di asrama yang menjadi ciri khas pondok pesantren; dan (h) Mendorong dan memotivasi para santri untuk terus belajar dan mengembangkan setiap potensi yang dimilikinya agar bisa mengharumkan nama pesantren. 


\section{DAFTAR RUJUKAN}

Aly, Abdullah. 2011. Pendidikan Islam Multikultural Di Pesantren. Yogyakarta: Pustaka Pelajar.

Aly, Abdullah. 2008. pendidikan Islam multikultural di pesantren: telaah terhadap kurikulum pondok pesantren modern Islam Assalam Surakarta Tahun 2006/2007. Disertasi, diajukan pada Program Pascasarjana UIN Sunan Kalijaga Yogyakarta.

Arifin, Zainal. 2011. Penelitian Pendidikan Metode dan Paradigma Baru. Bandung Remaja Rosdakarya.

Assegaf, Abd. Rahman. 2011. Filsafat Pendidikan Islam. Jakarta: Rajawali Press.

Daulay, H. Haidar Putra. 2004. Pendidikan Islam dalam Sistem Pendidikan Nasional. Jakarta: Kencana.

Hasil wawancara dengan Ibu Asriani Hamzah, pembina pondok pesantren DDI-AD Mangkoso. Tanggal, 12 November 2013.

Maksum, Ali. 2001. Pluralisme dan Multikulturalisme Paradigma Baru Pendidikan Agama Islam di Indonesia. Yogyakata: Aditya Media Publishing.

Naim, Ngainun dan Sauqi, Ahmad. 2011. Pendidikan Multikultural, Konsep dan Aplikasi. Yogyakarta: Ar-Ruzz Media.

Rahardjo, M. Dawam. 1995. Pesantren dan Pembaharuan. Jakarta: PT. Pustaka LP3ES Indonesia.

$\begin{array}{ccr}\text { Soenhaji } & \text { Saleh, } & \text { Dinamika } \\ \text { Pesantren:Dampak } & \text { Pesantren } \\ \text { Dalam } & \text { Pendidikan } & \text { dan }\end{array}$
Pengembangan
Masyarakat, Jakarta: P3M, 1988.

Sulalah. 2012. Pendidikan Multikultural: Didaktika Nilai-Nilai Universalitas Kebangsaan. Malang: UIN-Maliki Press.

Thobroni, Muhammad dan Mustafa, Arif. 2011. Belajar dan Pembelajaran: Pengembangan Wacana dan Praktik Pembelajaran dalam Pembangunan Nasional. Yogyakarta: Ar-Ruzz Media.

Tilaar, H.A.R., 2009. Kekuasaan Dan Pendidikan. Jakarta: Rineka Cipta.

Ujan, Andre Atan dkk., 2009. Multikulturalisme: Belajar Hidup bersama dalam perbedaan. Jakarta: PT Indeks.

Yaqin, M. Ainul. 2005. Pendidikan Multikultural, Cross-Cultural Understanding Untuk Demokrasi dan Keadilan. Yogyakarta: Pilar Media.

Yasmadi. 2002. Modernisasi Pesantren: Kritik Nurcholish Madjid Terhadap Pendidikan Islam Tradisional. Jakarta: Ciputat Press.

Ziemek, Manfred. t.t. Pesantren dalam Perubahan Sosial. Jakarta: P3M Penghimpunan Pengembangan Pesantren dan Mayarakat.

\section{WEBSITE}

Http://www.referensimakalah.com/20 $12 / 11$ /pengertian-pendidikanmultikultural.html. di akses tanggal 16 november 2013.

Http.id.

wikipedia/wiki/multikulturalisme . Diunduh tanggal 05 september 2013. 